\title{
A Comparison of Levels of Select Minerals in Scalp Hair Samples with Estimated Dietary Intakes of These Minerals in Women of Reproductive Age
}

\author{
J. Suliburska
}

Received: 21 February 2011 / Accepted: 9 March 2011 /

Published online: 29 March 2011

C The Author(s) 2011. This article is published with open access at Springerlink.com

\begin{abstract}
The objective of this study was to evaluate daily intake of minerals and concentrations of minerals in hair in women of reproductive age. The study included 77 menstruating women, aged $35.9 \pm 9.7$ years. Subjects were divided into three groups according to age. All women were healthy. Hair samples were taken from several points of the occipital scalp. The content of minerals in hair samples was determined by flame atomic absorption spectrometry. Dietary intake of the analysed minerals was assayed on the basis of dietary intake interviews from three preceding days and evaluated using the dietetic computer programme. It was shown that calcium and iron daily intake by the women was below the recommended value. Only few women had low concentrations (below reference values) of magnesium, copper and zinc in hair. Statistically significant differences were shown between age groups. Generally, the concentrations of minerals in hair in the younger (19-30 years) and the older women (41-50 years) were higher than in hair of middle-aged women (31-40 years). The content of calcium, magnesium, iron and zinc in daily diets of women correlated inversely with copper level in their hair. Food products with good bioavailability of iron and calcium should be recommended for women of childbearing age in all age groups.
\end{abstract}

Keywords Women $\cdot$ Minerals $\cdot$ Hair $\cdot$ Nutrition

\section{Introduction}

Women of child bearing age are at high risk of mineral deficiency, especially of iron. Iron deficiency is the most common nutrient deficiency in the developed countries. Low iron stores occur with relatively high frequencies in fertile women and with lower frequencies in postmenopausal women. Young women are at high risk because of the effects of menstruation and pregnancy $[1,2]$. Osteoporosis is a significant source of morbidity for older women. However, it has been found that low calcium stores in premenopausal women expose them to the risk of development of this disease at an old age [3, 4].

J. Suliburska $(\bowtie)$

Department of Hygiene and Human Nutrition, Poznan Life Science University, Wojska Polskiego 31, 60-624 Poznan, Poland

e-mail: jsulibur@up.poznan.pl 
Some health disorders common in women are closely associated with mineral status in their organisms and with eating habits. Poor diet quality and low bioavailability of dietary minerals are important factors that contribute to iron deficiency. Low dietary intake of calcium could be involved in the pathogenesis of osteoporosis in women. Zinc, copper and magnesium disorders lead to metabolic diseases [5-7].

To assess mineral status of the organism, mineral concentrations are determined in various biological materials (e.g. serum, urine). Some authors believe that head hair may be a good mineral body biomarker and it provides retrospective information on the exposure and nutritional status of individuals, making it possible to trace nutrient intake [8].

Wójciak et al. [5] are of the opinion that the first inch of hair closest to the scalp can give a good indication of the nutrient mineral exposure over the previous 6-8 weeks. It is assumed that trace elements in hair reflect trace elements in organs or important body pools. The studies of other authors showed that copper in hair correlates significantly with copper in the liver, heart and kidneys. Similarly, zinc in hair correlates significantly with zinc in bones [9]. Song et al. [10] reported an association of serum and hair levels of calcium and magnesium with bone density in premenopausal women.

The objective of this study was to evaluate daily intake of minerals and concentrations of minerals in hair in reproductive age women.

\section{Subjects and Methods}

\section{Subjects}

The study protocol was approved by the Bioethics Commission at the Poznan University of Medical Sciences-bioethics commission approval no. 07/08.

The study was carried out on 77 menstruating women, aged $35.9 \pm 9.7$ years. Subjects were divided into three groups according to their age. All women were healthy. Obese and smoking women were excluded from this study. Some of the subjects $(40 \%)$ suffered from hypermenorrhoea. About $30 \%$ of the women took oral contraceptives. Before the study, participants were asked to restrain from mineral supplementation. Most of the women (60\%) gave birth to at least one child. The full characteristics for the subjects are presented in Table 1. All subjects were informed about the study aim, procedures and measurement methods, and the individual consent of each patient was obtained.

Table 1 Characteristics of women participating in the study

\begin{tabular}{|c|c|c|c|c|}
\hline Parameter & All $(n=77)$ & $\begin{array}{l}\text { Age } 19-30 \\
(n=28)\end{array}$ & $\begin{array}{l}\text { Age } 31-40 \\
(n=25)\end{array}$ & $\begin{array}{l}\text { Age } 41-50 \\
(n=24)\end{array}$ \\
\hline Age (years) & $35.9 \pm 9.7$ & $24.2 \pm 4.3$ & $34.8 \pm 5.2$ & $44.8 \pm 4.6$ \\
\hline BMI $\left(\mathrm{kg} / \mathrm{m}^{2}\right)$ & $23.9 \pm 3.5$ & $20.9 \pm 2.1$ & $24.2 \pm 4.6$ & $25.2 \pm 3.8$ \\
\hline Hypermenorrhoea (\% of subjects) & 39.5 & 32.0 & 29.0 & 58.0 \\
\hline $\begin{array}{l}\text { Oral contraceptive ( } \% \text { of subjects) } \\
\text { (for at least } 3 \text { months) }\end{array}$ & 28.6 & 39.0 & 36.0 & 8.0 \\
\hline $\begin{array}{l}\text { Mineral supplementation ( } \% \text { of subjects) } \\
\text { (for at least } 3 \text { months) }\end{array}$ & 0 & 0 & 0 & 0 \\
\hline Births (\% of subjects) & 59.7 & 18.0 & 76.0 & 92.0 \\
\hline
\end{tabular}


Anthropometric Assessment

Anthropometric measurements of individuals wearing light clothing and no shoes were conducted. Weight was measured to the nearest $0.1 \mathrm{~kg}$, and height was measured to the nearest $0.1 \mathrm{~cm}$. BMI was calculated by dividing weight (kilogrammes) by height squared (square metre).

\section{Dietary Assessment}

Dietary intake of the analysed minerals was assayed on the basis of dietary intake interviews from three preceding days $(3 \times 24$-h recall $)$ developed by the National Food and Nutrition Institute [11]. Dietary interviews were taken in the middle of the menstrual cycle. The amount of minerals in the daily diet was processed and evaluated using the dietetic computer programme.

\section{Biochemical Assay}

Hair samples ( $1 \mathrm{~cm}$ from the scalp; $\sim 0.5 \mathrm{~g}$ ) taken from six points of the occipital scalp were collected from each individual. Samples were washed in acetone, deionised water and acetone, then dried to constant weight at $105^{\circ} \mathrm{C}$, and subsequently mineralized in a mixture of concentrated nitric $(65 \%)$ and perchloric $(60 \%)$ acids (suprapure, Merck) $(v / v 1: 1)$ in the MW oven (Milestone). Calcium, magnesium, iron, copper and zinc concentrations were assayed in each hair sample.

Contents of minerals in hair samples were determined by flame atomic absorption spectrometry (a Zeiss AAS-3 spectrometer with deuterium background correction). The accuracy of the method was verified by certified reference material. It amounted to $95 \%$, 99\%, 94\%, 99\% and 102\% for $\mathrm{Ca}, \mathrm{Mg}, \mathrm{Fe}, \mathrm{Zn}$ and $\mathrm{Cu}$, respectively. Reference values for the contents of hair minerals were established on the basis of published data [5].

\section{Statistical Analysis}

Data were analysed using Statistica 6.0 (StatSoft). The key descriptive parameters, i.e. arithmetic mean, standard deviation and median, were calculated. Mann-Whitney's test was used to establish the significance of differences between groups for independent variables. Statistical correlations between parameters were analysed by Spearman's correlation test. A $p$ value of less than 0.05 was considered statistically significant.

\section{Results}

The results obtained in this study are presented in Tables 2 and 3. Table 2 shows that the contents of calcium and iron in the daily food rations (DFR) of each studied group were inadequate. However, the intake of minerals with DFR by women aged 41-50 years was the highest. An extremely low intake of iron (slightly above $50 \%$ of recommended daily allowance (RDA)) was recorded in younger women (19-30 years). There were no statistically significant differences in DFR minerals content between age groups.

Mean hair calcium, magnesium, iron, copper and zinc contents were within $(\mathrm{Fe}, \mathrm{Cu})$ or above $(\mathrm{Ca}, \mathrm{Mg}, \mathrm{Zn})$ reference ranges (Table 3). Only few women had low concentrations (below reference values) of magnesium, iron, copper and zinc in hair. Statistically 
Table 2 Contents of minerals in DFR of women in terms of their age

\begin{tabular}{|c|c|c|c|c|c|}
\hline Parameter & \multicolumn{5}{|c|}{ (mg/person/day) } \\
\hline \multicolumn{6}{|l|}{ Age $19-30(n=28)$} \\
\hline Mean \pm SD & $751 \pm 251$ & $291 \pm 74.6$ & $9.7 \pm 2.66$ & $1.09 \pm 0.3$ & $8.61 \pm 2.27$ \\
\hline Median & 778 & 294 & 9.23 & 1.06 & 8.62 \\
\hline Min-max & $244-1,171$ & $146-443$ & $5.11-14.9$ & $0.60-1.84$ & $4.47-12.7$ \\
\hline$\%$ Realization of norm ${ }^{a}$ & 75.1 & 93.9 & 53.9 & 121.1 & 107.6 \\
\hline \multicolumn{6}{|l|}{ Age $31-40(n=25)$} \\
\hline Mean \pm SD & $780 \pm 287$ & $298 \pm 85.1$ & $10.1 \pm 3.01$ & $1.09 \pm 0.29$ & $9.17 \pm 2.65$ \\
\hline Median & 814 & 277 & 9.46 & 1.03 & 8.85 \\
\hline Min-max & $291-1,288$ & $151-461$ & $6.45-18.0$ & $0.66-1.82$ & $4.6-15.9$ \\
\hline$\%$ Realization of norm & 78.0 & 93.1 & 56.1 & 121.1 & 114.6 \\
\hline \multicolumn{6}{|l|}{ Age $41-50(n=24)$} \\
\hline Mean \pm SD & $818 \pm 337$ & $321 \pm 70.5$ & $10.5 \pm 1.34$ & $1.22 \pm 0.21$ & $9.92 \pm 1.98$ \\
\hline Median & 866 & 310 & 10.8 & 1.29 & 9.63 \\
\hline Min-max & $444-1,688$ & $215-452$ & $7.3-12.3$ & $0.88-1.55$ & $6.81-14.4$ \\
\hline$\%$ Realization of norm & 81.8 & 100.3 & 58.3 & 135.6 & 124.0 \\
\hline
\end{tabular}

mean arithmetic mean, $S D$ standard deviation, min minimum, max maximum

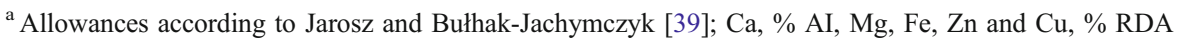

Table 3 The content of selected minerals in hair of women in terms of their age

\begin{tabular}{|c|c|c|c|c|c|}
\hline Parameter & $\mathrm{Ca}(\mu \mathrm{g} / \mathrm{g})$ & $\mathrm{Mg}(\mu \mathrm{g} / \mathrm{g})$ & $\mathrm{Fe}(\mu \mathrm{g} / \mathrm{g})$ & $\mathrm{Cu}(\mu \mathrm{g} / \mathrm{g})$ & $\mathrm{Zn}(\mu \mathrm{g} / \mathrm{g})$ \\
\hline \multicolumn{6}{|l|}{ Age $19-30(n=28)$} \\
\hline Mean \pm SD & $1,989 \pm 855$ & $110 \pm 52.4$ & $22.1 \pm 10.5$ & $25.8 \pm 19.4$ & $257.0 \pm 87.8$ \\
\hline Median & $1,735 b$ & $87.8 \mathrm{ab}$ & $20.4 b$ & $17.5 b$ & $232 b$ \\
\hline Min-max & $819-3,932$ & $56.9-223$ & $8.11-53.7$ & $7.60-67.7$ & $152-450$ \\
\hline$<\mathrm{RV}$ (\% of subjects) & 0 & 0 & 4 & 7 & 7 \\
\hline \multicolumn{6}{|l|}{ Age $31-40 \quad(n=25)$} \\
\hline Mean \pm SD & $1,400 \pm 627$ & $102 \pm 43.7$ & $12.3 \pm 10.9$ & $12.9 \pm 5.43$ & $219.0 \pm 28.7$ \\
\hline Median & $1,180 \mathrm{a}$ & $76.5 \mathrm{a}$ & $11.8 \mathrm{a}$ & $13.5 \mathrm{a}$ & $198 \mathrm{a}$ \\
\hline Min-max & $914-2,108$ & $56.8-167$ & $7.20-25.2$ & $7.17-17.9$ & $102-289$ \\
\hline$<\mathrm{RV}(\%$ of subjects $)$ & 0 & 0 & 10 & 10 & 20 \\
\hline \multicolumn{6}{|l|}{ Age $41-50(n=24)$} \\
\hline Mean \pm SD & $1,713 \pm 1,044$ & $128 \pm 61.1$ & $16.8 \pm 8.21$ & $17.6 \pm 4.15$ & $249 \pm 83.9$ \\
\hline Median & $1348 \mathrm{ab}$ & $133 b$ & $15.5 \mathrm{ab}$ & $16.6 \mathrm{~b}$ & $255 b$ \\
\hline Min-max & $909-3,247$ & $37.4-208$ & $9.95-27.5$ & $13.9-23.7$ & $149-335$ \\
\hline$<\mathrm{RV}$ (\% of subjects) & 0 & 7 & 7 & 0 & 7 \\
\hline
\end{tabular}

Significant correlation between $\mathrm{Cu}$ in hair and minerals in DFR: $\mathrm{Cu}-\mathrm{Fe}, R=-0.35 ; \mathrm{Cu}-\mathrm{Zn}, R=-0.35 ; \mathrm{Cu}-\mathrm{Ca}$, $R=-0.43 ; \mathrm{Cu}-\mathrm{Mg}, R=-0.50$. The letters a, b denote significant differences between age groups $p<0.05$, Mann-Whitney's test

$R V$ reference values [5] Ca, 400-1,000 $\mu \mathrm{g} / \mathrm{g} ; \mathrm{Mg}, 40-60 \mu \mathrm{g} / \mathrm{g} ; \mathrm{Fe}, 10-20 \mu \mathrm{g} / \mathrm{g} ; \mathrm{Cu}, 10-20 \mu \mathrm{g} / \mathrm{g} ; \mathrm{Zn}, 160-$ $200 \mu \mathrm{g} / \mathrm{g}$ 
significant differences were shown between age groups (Table 3). Generally, the concentrations of minerals in hair of the younger (19-30 years) and the older women (41-50 years) were higher than in hair of middle-aged women (31-40 years). Women aged 31-40 years had significantly lower calcium and iron levels in hair than women aged 19-30 years. Moreover, copper and zinc in hair of women between 31 and 40 years of age were markedly lower in comparison with the other groups. The concentration of magnesium in hair of women aged 19-30 years was significantly lower than in women aged 41-50 years. It was also found that a relatively high percentage of middle-aged women had concentrations of iron (10\%), copper $(10 \%)$ and zinc $(20 \%)$ in hair below reference values.

A significant relationship was observed between copper in hair and other minerals in DFR (Table 3). The contents of calcium, magnesium, iron and zinc in daily diets of women correlated inversely with copper level in hair of women.

\section{Discussion}

Studies conducted worldwide reported that women of reproductive age consumed low amounts of calcium, magnesium and iron.

In some studied populations, over $60 \%$ of women had calcium intakes lower than $200 \mathrm{mg}$ per day $[12,13]$. The results of a study by Islam et al. [12] suggested that a low calcium intake could reduce bone accretion rates and increase the risk of osteoporosis in women aged 16-40 years. In this study, it was also observed that daily supply of calcium in women was below the recommended value. The National Health and Nutrition Survey reported that young women consumed approximately $75 \%$ of the recommended calcium amount of 1,000 mg/day. Both in the United States and in Poland in young women the largest and most frequently consumed calcium sources are milk and dairy products $[14,15]$. In addition, the use of oral contraceptives (OC) may decrease calcium level in the organism. National, population-based data showed lower bone mass density (BMD) in premenopausal women who have used OC as compared with those who have never used OC [16]. Low BMD indicates osteoporosis that is often caused by a low calcium intake. The studies showed that a low magnesium level in the serum is also correlated with low bone mass density [6].

Iron deficiency is also common among women at reproductive age [17, 18]. Ortega et al. [19], Shams et al. [20] and Haidar [21] observed that female adolescents are a group susceptible to anemia and micronutrient (especially iron) deficiencies. Kabir et al. [22] showed that the prevalence of anemia among adolescent girls was $23 \%$, and their habitual dietary pattern indicated poor consumption of iron-rich foods. In the Polish study, it was also found that dietary supply of iron in female students was below the recommended intake (only 47-65\% RDA) [13, 15]. For comparison in this study, iron content in the diet of women ranged from $54 \%$ to $58 \%$ of the recommended value.

Analyses of Backstrand [18] showed that a better iron status was associated with higher intakes of non-heme iron, ascorbic acid and foods that contain ascorbic acid. The low bioavailability of iron from diets in developing and industrialized countries is an additional problem influencing poor iron availability and body iron stores and contributing to an increased risk of iron deficiency anemia among female populations [23]. The most important sources of dietary iron are foods that are rich in highly bioavailable forms of iron (supplemental iron and red meat) and fruit promoting high iron stores [24]. In other studies, it was observed that polyphenols and phytic acid in food decreased iron 
bioavailability in young women, while lowering the level of inhibitors in the diet increased iron absorption [25].

A study of Chandyo [26] indicated that there was a high prevalence of zinc deficiency in women of reproductive age in Nepal. Moreover, the above-mentioned authors showed that foods rich in zinc contain also phytate, which reduces zinc absorption. Gibson and Huddle [27] showed that zinc deficiency in women is associated with low intakes of poorly available zinc. Yokoi et al. [28] found that premenopausal hypozincemic women had higher hair $\mathrm{Zn}$ concentrations than the normozincemic women. Those authors explained that in adults' hair, $\mathrm{Zn}$ was increased by $\mathrm{Zn}$ deprivation. In this study, no relationship was observed between the supply of zinc and zinc level in hair.

The concentration of minerals in hair of young women found in this study corresponded with the literature data [29]; however, in older women these data were slightly higher than the results reported by Skalnaya and Demidov [30] and Suliburska et al. [31]. Interestingly, markedly higher concentrations of copper and markedly lower levels of zinc were observed in hair of women from India [32].

There are only few data on hair mineral analyses in women and their correlation with dietary intake. In this study, no association was found between mineral intake and their content in hair of women. It may be caused by the fact that mineral contents in hair reflect the nutritional status of the organism over a longer period of time (about 6-8 weeks), while the data on consumption were collected in the middle of the menstrual cycle (3 days).

What is more, some authors did not confirm any relationship between hair concentration of minerals and their daily intake in adult subjects. Lahti-Koski et al. [1] found that food consumption was poorly associated with iron status [1]. Gonzalez-Munoz et al. [33] did not observe any correlation between trace element intakes and their corresponding levels in hair [33]. However, other studies showed that hair mineral content reflects exposure of elements from the diet [34].

Interestingly, a significant negative correlation was found between copper in hair and other minerals in daily food rations. The negative correlation between copper in hair and the intake of other elements, demonstrated in this study, is probably due to the interaction between the minerals. These interactions occur at the stage of their absorption and transport. Copper is essential for iron transport between tissues [35]. It was found that the intake of zinc affects copper status. The zinc-copper interaction probably takes place at the absorption level [35].

Other studies showed that the concentrations of zinc and copper in hair were lower in patients with iron deficiency anemia [36]. In this study, the lowest concentration of zinc and copper was recorded in hair of women aged between 31 and 40 years. It was found that the intake of iron was very low in all women, and it is possible that iron deficit in the organism could increase with age, especially in pregnant and breastfeeding women.

Wlazlak et al. [37] found that hair copper concentration in perimenopausal women decreases with age. This study did not completely confirm this conclusion; however, these data showed that the arithmetic average of copper content in hair in women under 30 was higher than in older women (Table 3).

Deeming and Weber [38] showed that mean hair copper level decreased and mean hair zinc content increased with oral contraceptive use in women. In this study, a large proportion of women aged 31-40 years took oral contraceptives, and it was observed that hair copper level was the lowest in this age group as compared with other groups of women.

For an appropriate functioning of the organism, not only contents of minerals are important, but also appropriate proportions between them. Proportions between copper and 
zinc in the body are particularly important, since antagonistic interactions occur between them. In this study, the highest mean contents of copper and zinc were recorded in the group of the youngest women, in which the highest mean copper to zinc ratio was found $(\mathrm{Cu}$ to $\mathrm{Zn}=0.075)$. With age, the contents of copper and zinc in hair of women decreased, but the reduction of copper content was much higher than that of zinc, in women aged 3140 years the $\mathrm{Cu}$ to $\mathrm{Zn}$ ratio was 0.068 and it was similar to the value of the copper to zinc ratio in the oldest women $(\mathrm{Cu}$ to $\mathrm{Zn}=0.065)$.

The reduction of copper and zinc levels in women aged 31-40 years was most probably a consequence of the fact that at present women most frequently in that decade of their lives become pregnant, they also frequently use contraceptives. These elements play a very important role in the development of the embryo and readily penetrate the placenta, as a result of which their content in the organism of the mother decreases. Moreover, as it was already mentioned, copper content in hair decreases, while zinc content increases as a result of the administration of contraceptives. The reduction of copper content in relation to zinc in hair of women in the second and third age groups could have resulted from the more rapid changes in the state of nutrition of the organism with copper and secondly, also from the antagonism between elements, e.g. at the stage of absorption.

\section{Conclusions}

1. The intake of calcium and iron is markedly below the recommended value in women of reproductive age.

2. The concentration of minerals in hair of women is associated with age. The lowest content of analysed minerals is found in women between 31 and 40 years.

3. The content of copper in hair inversely correlates with the daily intake of calcium, magnesium, iron and zinc in women.

4. Food products with good bioavailability of calcium and iron should be recommended for women of childbearing age in all age groups.

Open Access This article is distributed under the terms of the Creative Commons Attribution Noncommercial License which permits any noncommercial use, distribution, and reproduction in any medium, provided the original author(s) and source are credited.

\section{References}

1. Lahti-Koski M, Valsta LM, Alfthan G, Tapanainen H, Aro A (2003) Iron status of adults in the capital area of Finland. Eur J Nutr 42:287-292

2. Milman N, Byg KE, Ovesen L (2000) Iron status in Danes 1994. Ann Hematol 79:612-621

3. Hardcastle AC, Aucott L, Fraser WD, Reid DM, Macdonald HM (2011) Dietary patterns, bone resorption and bone mineral density in early post-menopausal Scottish women. Eur J Clin Nutr 65:378-385

4. Sobaś K, Wądołowska L, Sowińska MA, Człapka-Matyasik M, Niedźwiedzka E (2010) Analysis of the occurrence of dietary and non-dietary factors of fracture risk in relation to bone mineral density in women. Acta Sci Pol Technol Aliment 9(3):373-382

5. Wojciak RW, Krejpcio Z, Czlapka-Matyasik M et al (2004) Comparison of the hair bioelements in vegetarian and non-vegetarian women. Trace Elem Electrolytes 21(3):141-144 
6. Saito N, Tabata N, Saito S et al (2004) Bone mineral density, serum albumin and serum magnesium. J Am Coll Nutr 23(6):701S-703S

7. Patterson AJ, Brown WJ, Roberts DCK et al (2001) Dietary treatment of iron deficiency in women of childbearing age. Am J Clin Nutr 74:650-656

8. Gellein K, Lierhagen S, Brevik PS, Teigen M, Kaur P, Singh T, Flaten TP, Syvyrsen T (2008) Trace element profiles in single strands of human hair determined by HR-ICP-MS. Biol Trace Elem Res 123:250-260

9. Klevay LM, Christopherson DM, Shuler TR (2004) Hair as a biopsy material: trace element data on one man over two decades. Eur J Clin Nutr 58:1359-1364

10. Song ChH, Barrett-Connor E, Chung JH, Kim SH, Kim KS (2007) Associations of calcium and magnesium in serum and hair with bone mineral density in premenopausal women. Biol Trace Elem Res 118:1-9

11. National Food and Nutrition Institute (1996) Instruction of 24-hour diet recall. Department of Epidemiology and Norms of Nutrition, Warsaw

12. Islam MZ, Lamberg-Allardti C, Karkkainen M et al (2003) Dietary calcium intake in premenopausal Bangladeshi women: do socio-economic or physiological factors play a role? Eur J Clin Nutr 57:674-680

13. Czapska D, Ostrowska L, Stefańska E et al (2009) Assessment of the levels of chosen mineral components in daily food rations of medical university students in the years 2002/2004 and 2008/2009. Bromatol Chem Toksykol 42(3):723-727 [English abstract]

14. Teegarden D, Legowski P, Gunther CW et al (2005) Dietary calcium intake protects women consuming oral contraceptives from spine and hip bone loss. J Clin Endocrinol Metab 90:5127-5133

15. Skibniewska K, Dymkowska-Malesa M, Siwik P et al (2007) Nutrive vallue of Olsztyn University students diet. Przegl Lek 64(Suppl 4):15-18 [English abstract]

16. Prior JC, Kirkland SA, Joseph L et al (2001) Oral contraceptives use and bone mineral density in premenopausal women: cross-sectional, population-based data from the Canadian multicentre osteoporosis study. CMAJ 165(8):1023-1029

17. Ramakrishnan U, Frith-Terhune A, Cogswell M et al (2002) Dietary intake does not account for differences in low iron stores among Mexican American and non-hispanic white women: third national health and nutrition examination survey, 1988-1994. J Nutr 132:996-1001

18. Backstrand JR, Allen LH, Black AK (2002) Diet and iron status of nonpregnant women in rural Central Mexico. Am J Clin Nutr 76:156-164

19. Ortega P, Leal J, Amaya D et al (2010) Nutritional evaluation, micronutrient deficiencies and anemia among female adolescents in an urban and a rural zone from Zulia state, Venezuela. Invest Clin 51 (1):37-52

20. Shams S, Asheri H, Kianmehr A (2010) The prevalence of iron deficiency anaemia in female medical students in Tehran. Singapore Med 51(2):116-119

21. Haidar J (2010) Prevalence of anaemia, deficiencies of iron and folic acid and their determinants in Ethiopian women. J Health Popul Nutr 28(4):359-368

22. Kabir Y, Shahjalal HM, Saleh F (2010) Dietary pattern, nutritional status, anaemia and anaemia-related knowledge in urban adolescent college girls of Bangladesh. JPMA 60:633-638

23. Seaverson EL, Buell JS, Fleming DJ (2007) Poor iron status is more prevalent in Hispanic than in nonHispanic white older adults in Massachusetts. J Nutr 137:414-420

24. Cade JE, Moreton JA, O'Hara B (2005) Diet and genetic factors associated with iron status in middleaged women. Am J Clin Nutr 82:813-820

25. Petry N, Egli I, Zeder C (2010) Polyphenols and phytic acid contribute to the low iron bioavailability from common beans in young women. J Nutr 140(11):1977-1982

26. Chandyo RK, Strand TA, Mathisen M (2009) Zinc deficiency is common among healthy women of reproductive age in Bhaktapur, Nepal. J Nutr 139:594-597

27. Gibson R, Huddle JM (1998) Suboptimal zinc status in pregnant Malawian women: its association with low intakes of poorly available zinc, frequent reproductive cycling, and malaria. Am J Clin Nutr 67:702-709

28. Yokoi K, Egger NG, Ramanujam VMS (2003) Association between plasma zinc concentration and zinc kinetic parameters in premenopausal women. Am J Physiol Endocrinol Metab 285:E1010-E1020

29. Chojnacka K, Michalak I, Zielinska A, Gorecka H, Gorecki H (2010) Inter-relationship between elements in human hair: the effect of gender. Ecotoxicol Environ Saf 73:2022-2028

30. Skalnaya MG, Demidov VA (2007) Hair trace element contents in women with obesity and type 2 diabetes. J Trace Elem Med Biol 21(S1):59-61

31. Suliburska J, Bogdański P, Pupek-Musialik D, Krejpcio Z (2011) Dietary intake and serum and hair concentrations of minerals and their relationship with serum lipids and glucose levels in hypertensive and obese patients with insulin resistance. Biol Trace Elem Res 139(2):137-150

32. Sukumar A, Subramanian R (2007) Relative element levels in the paired samples of scalp hair and fingernails of patients from New Delhi. Sci Total Environ 372:474-479 
33. Gonzalez-Munoz MJ, Pena A, Meseguer I (2008) Monitoring heavy metal contents in food and hair in a sample of young Spanish subjects. Food Chem Toxicol 46:3048-3052

34. Chojnacka K, Zielinska A, Michalak I, Gorecki H (2010) The effect of dietary habits on mineral composition of human scalp hair. Environ Toxicol Pharmacol 30:188-194

35. Sandstroem B (2001) Micronutrient interactions: effects on absorption and bioavailability. Br J Nutr 85 (suppl 2):S181-S185

36. Gurgoze MK, Olcucu A, Aygun DA (2006) Serum and hair levels of zinc, selenium, iron and copper in children with iron-deficiency anemia. Trace Elem Res 23(111):23-29

37. Wlazlak E, Dunicz-Sokolowska A, Radomska K (2007) Analysis of hair copper concentration in perimenopausal women. Przegląd Menopauzalny 5:303-305 [English abstract]

38. Deeming SB, Weber CW (1978) Hair analysis of trace minerals in human subjects as influenced by age, sex, and contraceptive drugs. Am J Clin Nutr 3:1175-1180

39. Jarosz M, Bułhak-Jachymczyk B (2008) Human nutrition norms. PZWL, Warsaw 